\title{
Effect of level of inclusion of clove (Syzygium aromaticum) powder in the diet on growth and histological changes in the intestines and livers of broiler chickens
}

\author{
S.I. Al-Mufarrej, H.H. Al-Baadani" \& E.H. Fazea \\ Department of Animal Production, College of Food and Agriculture Sciences, King Saud University, Saudi Arabia
}

(Received 20 July 2018; Accepted 20 January 2019; First published online 20 March 2019)

\author{
Copyright resides with the authors in terms of the Creative Commons Attribution 4.0 South African Licence. \\ See: http://creativecommons.org/licenses/by/4.0/za \\ Condition of use: The user may copy, distribute, transmit and adapt the work, but must recognise the authors and \\ the South African Journal of Animal Science.
}

\begin{abstract}
:
The study was designed to evaluate the effects of different levels of clove (Syzygium aromaticum) powder in the diet on growth performance and histological changes of the livers and intestines of broiler chickens at 21 and 35 days old. Three hundred and thirty-six one-day-old Ross (308) broilers were allocated to eight treatments, namely: NC: negative control and unvaccinated; PC: positive control and vaccinated; and treatments T1, T2, T3, T4, T5 and T6 supplemented with different levels of clove powder $(10,20,30,40$, 50 and $60 \mathrm{~g}$ clove powder/kg of diet, respectively) and all vaccinated. At 21 and 35 days old, eight birds/treatment were weighed, and samples from the livers and intestines were collected to evaluate morphological and histological changes. The results showed that higher levels of clove powder (T3 to T6) resulted in a gradual decrease in the live body weight of the birds at 21 and 35 days old. Relative liver weight increased in T5 and T6 at 35 days, but not at 21 days. A shorter small intestine was recorded in birds that received 50 and $60 \mathrm{~g}$ ( $\mathrm{T} 5$ and $\mathrm{T} 6$ ) clove powder, while the proportional length of small intestinal parts did not show differences among treatments at 21 and 35 days old. The supplementation in the T3 toT6 groups resulted in a gradual decrease in intestinal weight at 21 days, but was not evident at 35 days. Villus height, villus surface area and villus crypt depth showed a gradual decrease from T1 to T6 at 35 days old. Also, gradual loss was recorded of the intestinal epithelium structure by necrotic enteritis on the wall of villi with an increased level of clove powder $(<\mathrm{T} 2)$. These results indicated that $10 \mathrm{~g}$ clove powder per $\mathrm{kg}$ diet could be used to improve the growth rate without affecting the health of the liver and intestines of broilers.
\end{abstract}

Keywords: Gallus domesticus, morphology, histomorphometric, digestive system, vaccine

\# Corresponding author: hanee7811@gmail.com

\section{Introduction}

In recent years, the use of antibiotic growth promoters (AGPs) in poultry diets has raised concern about the development of antibiotic-resistant microbes and their effect on human health (Smith et al., 2003; Castanon, 2007). Consequently, there is a trend in many investigations to seek for possible replacemenst for AGPs in broiler chicken diets, such as probiotics, prebiotics, organic acids and enzymes (Rosin et al., 2007; Abudabos et al., 2015), plant extracts, herbs and medicinal plants (Amaechi \& Anueyiagu, 2012; Tripathi et al., 2013; Chowdhury et al., 2018), and spices such as cloves (Ghazanfari et al., 2014).

Cloves contain vitamin A (retinol), beta-carotene (Dorman et al., 2000), and vitamins K, $\mathrm{B}_{6}, \mathrm{~B}_{1}$ and C (Nadkarni, 2000). Most importantly, cloves contain a phenolic compound (eugenol), which is its main bioactive ingredient (72\% - 90\%) (Ertas et al., 2005; Li-Ming et al., 2012).

The inclusion of $0.50 \%$ clove powder $/ \mathrm{kg}$ diet can be used as a growth promoter in Japanese quail (Tariq et al., 2015). This was confirmed by Agostini et al. (2012), who reported that clove powder (0.1 - 2.5 $\mathrm{g} / \mathrm{kg}$ diet) had a positive effect on growth performance, feed efficiency and changes in the intestine epithelium of broiler chickens. On the other hand, the inclusion levels of 1.0 and $1.5 \mathrm{~g}$ of clove powder $/ \mathrm{kg}$ diet did not affect growth performance parameters, but improved the health of broiler chickens (Mahrous et al., 2017). The use of cloves at levels higher than these levels may have minimal effect on growth rate through a reduction in feed palatability, or may affect the intestinal epithelium and liver cells that alter digestion, absorption and metabolism. However, the clove is a safe plant when consumed in concentrations 
lower than $1.5 \mathrm{~g} / \mathrm{kg}$ (Cortés-Rojas et al., 2014). Moreover, Walum (1998) reported that lethal doses of extract of clove were recorded as $2500 \mathrm{mg} / \mathrm{kg}$, which shows that it is relatively safe, as classified by the Organization for Economic Cooperation and Development (OECD, Paris-France). However, this does not constitute a biological constant because of factors such as species, age and diet (Adam et al., 2013). Thus, it is important to establish appropriate inclusion levels of cloves and its essential oil as growth promoters (Najafi \& Torki, 2010).

It was hypothesized that changes in digestibility, the intestinal microbiota and the intestinal mucosa are involved in the mechanism of action of cloves. Therefore, the purpose of this study was to evaluate the effect of high levels of clove powder on growth performance and histological changes of the liver and intestines of broiler chickens.

\section{Materials and Methods}

Three hundred and thirty-six one-day-old mixed sex broiler chicks (Ross 308) were obtained from a commercial hatchery. Based on similar body weights, all chicks were divided randomly into 48 experimental cages with seven chicks per cage. This experiment was conducted in an environmentally controlled battery room. The temperature of the room was kept at $35^{\circ} \mathrm{C}$ for the first day post hatch and gradually reduced to 22 ${ }^{\circ} \mathrm{C}$ at the end of the experiment.

Birds were fed a starter diet from 0 to 14 days $(21.5 \%$ crude protein and metabolizable energy, 3000 $\mathrm{kcal} / \mathrm{kg}$ diet) and a finisher diet from 15 to 35 days (21\% crude protein and metabolizable energy, 3100 $\mathrm{kcal} / \mathrm{kg}$ diet), based on corn and soybean meal. Diets were formulated according to the recommendations of the Ross Management Guide. Dietary treatments were allocated randomly into eight groups with six replicate (cage), namely: a negative control (NC) (without addition of clove powder and not vaccination), a positive control (PC) (without addition of clove powder but vaccination), and treatments T1, T2, T3, T4, T5 and T6 where the basal diet was supplemented with different levels of clove powder $(10 \mathrm{~g}, 20 \mathrm{~g}, 30 \mathrm{~g}, 40 \mathrm{~g}, 50 \mathrm{~g}$ and $60 \mathrm{~g}$ per $\mathrm{kg}$ of diet, respectively). Whole cloves were obtained from the market and ground to use as a powder. Birds in treatments PC and T1 to T6 were vaccinated against Infectious Bronchitis and Newcastle disease at 5 and 21 days old, as well as against infectious bursal disease at 14 days old.

On days 21 and 35, eight birds from each dietary treatment were slaughtered after being weighed $(\mathrm{g})$ and the entire small intestine and liver were removed. The liver as a percentage of live bodyweight was calculated, and total small intestine was weighed $(\mathrm{g})$, and length measurements were taken in centimetres $(\mathrm{cm})$. The length and weight of the intestine were used to calculate the intestine-weight-to-length ratio (W/L). Additionally, the lengths of the duodenum, jejunum and ileum were calculated as percentages of the total length of the small intestine $(\mathrm{cm})$.

A 3-cm-long tissue sample was taken from the midpoint of the ileum of the small intestine without straining the intestinal wall. This site is considered the basis of microbial activity and the main site of absorption of most nutrients (Bryden et al., 2009). Additionally, a tissue sample was taken from the midpoint of the liver from each bird.

Tissue samples were fixed in $10 \%$ (vol/vol) phosphate-buffered formalin for 48 hours, then dehydrated in graded alcohol and paraffin embedded into the action sections. Sections of $5 \mu \mathrm{m}$ from each tissue were cut using the Microtome System, and stained with haematoxylin and eosin (H\&E) according to the method of Mohamed et al. (2014). Measurements of villus length $(\mu \mathrm{m})$, width $(\mu \mathrm{m})$ and crypt depth $(\mu \mathrm{m})$ were based on at least eight intact villi per section/bird, using a microscope and image analysis system (Olympus DP72 microscope digital camera; Olympus NV, Aartselaar, Belgium). Villus length and crypt depth data were used to calculate the ratio, villus length/crypt depth. Additionally, villus height and width data were used to calculate villus surface area:

$$
\begin{aligned}
& \text { Surface area }\left(\mathrm{mm}^{2}\right)=[2 \pi \times(\mathrm{W} / 2) \times \mathrm{L}] \\
& \text { where: } \quad W=\text { villus width, } \\
& \quad \mathrm{L}=\text { villus length (Al-Baadani et al., 2016) }
\end{aligned}
$$

Histopathological changes in the samples were examined microscopically (100 to 300x). Changes in liver and ileum of the small intestine in all samples of the various treatments were based on the method described by Belih et al. (2015).

Data were evaluated by ANOVA for a complete randomized design. Data were tested for the main effect of dietary treatment, using the general linear model procedures of SAS software (SAS, 2008). The statements of statistical differences based on $P<0.05$ and differences between means were examined using Duncan's multiple range test. All values expressed as means \pm standard error of the means (SEM). 


\section{Results and Discussion}

The effects of treatments on the live bodyweight and relative liver weight at 21 and 35 days old are shown in Table 1. This study indicated that the inclusion of various levels of clove powder $(20 \mathrm{~g}, 30 \mathrm{~g}, 40 \mathrm{~g}$, $50 \mathrm{~g}$ and $60 \mathrm{~g} / \mathrm{kg})$ in T2 to T6 resulted in a gradual decrease $(P<0.0001)$ in live bodyweight at 21 days old compared with treatments T1, NC and PC. However, the relative liver weight was not influenced $(P>0.05)$ by treatment. At 35 days old, different levels of cloves in nutritional therapies T3, T4, T5 and T6 resulted in a gradual decrease $(P<0.0001)$ in the bodyweight, while relative liver weight increased in treatments T5 and T6 $(P<.0001)$. However, T6 had a lower live bodyweight and higher relative liver weight than the other treatments. The current results agree with the findings of Agostini et al. (2012), who showed that clove powder improved the growth performance of broiler chickens, but it depended on the dose in a non-linear way, with the optimum dose being $2500 \mathrm{mg} / \mathrm{kg}$ of diet. That could explain the reduction in feed intake, which was associated with high levels of cloves, and might affect palatability because of the impact of eugenol that act as analgesic and thus reduce gut movement (Daniel et al., 2009). It may also be due to changes in the intestinal epithelium, which led to poor digestion and absorption, which would be reflected in the growth rate of birds. High levels of cloves may inhibit the intestinal absorption of some nutrients (Kreydiyyeh et al., 2000), though the inclusion of levels at $1.0 \mathrm{~g}$ and $1.5 \mathrm{~g}$ clove/kg diet did not affect growth performance parameters, and enhances immunity and antioxidant activity of broiler chickens (Mahrous et al., 2017). However, at 21 and 35 days old, there were no significant differences between vaccinated birds (PC) and unvaccinated birds (NC) in live bodyweight and liver weight, as observed in the authors' previous experiment on the performance of birds (unpublished).

Table 1 Effect of clove powder levels on live body weight and liver as percentages of broiler chickens at 21 and 35 days old

\begin{tabular}{lcccc}
\hline \multirow{2}{*}{ Treatment } & \multicolumn{2}{c}{ 21 days } & 35 days \\
\cline { 2 - 5 } & Live body (g) & Liver (\%) & Live body (g) & Liver (\%) \\
\hline NC & $859.0^{\mathrm{a}}$ & 2.81 & $2501.0^{\mathrm{a}}$ & $1.92^{\mathrm{c}}$ \\
PC & $798.0^{\mathrm{a}}$ & 2.93 & $2421.7^{\mathrm{a}}$ & $2.00^{\mathrm{bc}}$ \\
T1 & $816.8^{\mathrm{a}}$ & 3.10 & $2340.3^{\mathrm{a}}$ & $2.00^{\mathrm{bc}}$ \\
T2 & $699.6^{\mathrm{b}}$ & 2.93 & $2358.2^{\mathrm{a}}$ & $2.09^{\mathrm{abc}}$ \\
T3 & $565.6^{\mathrm{c}}$ & 3.01 & $2167.1^{\mathrm{b}}$ & $2.26^{\mathrm{abc}}$ \\
T4 & $537.0^{\mathrm{c}}$ & 3.30 & $1868.7^{\mathrm{c}}$ & $2.13^{\mathrm{abc}}$ \\
T5 & $392.6^{\mathrm{d}}$ & 3.24 & $1691.2^{\mathrm{d}}$ & $2.38^{\mathrm{a}}$ \\
T6 & $369.3^{\mathrm{d}}$ & 2.50 & $1490.0^{\mathrm{e}}$ & $2.36^{\mathrm{a}}$ \\
SEM & 26.811 & 0.181 & 59.094 & 0.114 \\
P-value & $<.0001$ & 0.0913 & $<.0001$ & 0.0406
\end{tabular}

\footnotetext{
${ }^{a-e}$ Mean value within a column with different superscripts is significantly different $P<0.0001$. Data effect of treatment is a means of eight replicate birds $(n=8)$ of dietary treatment each

NC: negative control, without addition of clove powder and not vaccinated; PC: positive control without addition of clove powder and vaccinated; T1, T2, T3, T4, T5 and T6: different levels of clove powder $(10,20,30,40,50$ and $60 \mathrm{~g} / \mathrm{kg}$ diet, respectively) and vaccinated

SEM: standard error of mean
}

The small intestine is the site of most digestion and practically all absorption of nutrients (Svihus, 2014). The morphology of the small intestine reflects the health status of broilers, and is related to the capacity of nutrient assimilation and immunological functions (Nicholson et al., 2012). In the current study the intestinal morphology (length and weight of the small intestine) was recorded to assess functional changes when feeding birds various levels of cloves (Tables 2 and 3). At 21 days, old the length and weight of small intestine and W/L were affected $(P<0.001)$ by treatments, while the proportion of length of small intestine parts did not show differences among treatments $(P>0.05)$ (Table 2). Shorter small intestine was obtained in birds that received T5 and T6 $(135.46 \mathrm{~cm}$ and $124.90 \mathrm{~cm}$, respectively) compared with all other treatments. 
On the other hand, birds that had received T3, T4, T5 and T6 had lower weight and W/L than the controls, $\mathrm{NC}$ and PC.

Table 2 Effect of clove powder levels on the intestinal morphology of broiler chickens at 21 days old

\begin{tabular}{|c|c|c|c|c|c|c|}
\hline \multirow{2}{*}{ Treatment } & \multirow{2}{*}{$\begin{array}{l}\text { Intestine } \\
\text { length (cm) }\end{array}$} & \multicolumn{3}{|c|}{ Small intestine length (\%) } & \multirow{2}{*}{$\begin{array}{l}\text { Intestine } \\
\text { weight (g) }\end{array}$} & \multirow{2}{*}{$\begin{array}{l}\text { W/L ratio }{ }^{1} \\
(\mathrm{~g} / \mathrm{cm})\end{array}$} \\
\hline & & Duodenum & Jejunum & Ileum & & \\
\hline NC & $153.18^{\mathrm{ab}}$ & 16.76 & 41.60 & 41.68 & $42.50^{\mathrm{a}}$ & $0.27^{\mathrm{a}}$ \\
\hline PC & $153.11^{\mathrm{ab}}$ & 15.86 & 41.78 & 42.33 & $42.78^{\mathrm{a}}$ & $0.28^{\mathrm{a}}$ \\
\hline T1 & $164.83^{\mathrm{a}}$ & 16.16 & 41.86 & 41.98 & $43.93^{\mathrm{a}}$ & $0.26^{\mathrm{ab}}$ \\
\hline $\mathrm{T} 2$ & $151.38^{\mathrm{ab}}$ & 16.93 & 41.68 & 41.38 & $36.75^{\mathrm{ab}}$ & $0.24^{\mathrm{abc}}$ \\
\hline T3 & $147.61^{\mathrm{bc}}$ & 17.00 & 43.25 & 39.71 & $33.31^{b}$ & $0.22^{\mathrm{bc}}$ \\
\hline T4 & $161.35^{\mathrm{ab}}$ & 16.78 & 42.01 & 41.20 & $34.41^{b}$ & $0.21^{\mathrm{cd}}$ \\
\hline T5 & $135.46^{\mathrm{cd}}$ & 17.11 & 41.25 & 41.63 & $29.63^{b}$ & $0.22^{\mathrm{bcd}}$ \\
\hline T6 & $124.90^{\mathrm{d}}$ & 17.86 & 39.76 & 42.31 & $22.40^{\mathrm{C}}$ & $0.17^{\mathrm{d}}$ \\
\hline SEM & 4.3380 & 0.595 & 1.031 & 0.955 & 2.432 & 0.014 \\
\hline$P$-value & $<.0001$ & 0.421 & 0.539 & 0.6154 & $<.0001$ & 0.0001 \\
\hline
\end{tabular}

Table 3 Effect of clove powder levels on the intestinal morphology of broiler chickens at 35 days old

\begin{tabular}{|c|c|c|c|c|c|c|}
\hline \multirow{2}{*}{ Treatment } & \multirow{2}{*}{$\begin{array}{c}\text { Intestine } \\
\text { length }(\mathrm{cm})\end{array}$} & \multicolumn{3}{|c|}{ Small intestine length (\%) } & \multirow{2}{*}{$\begin{array}{l}\text { Intestine } \\
\text { weight (g) }\end{array}$} & \multirow{2}{*}{$\begin{array}{l}\text { W/L ratio }{ }^{1} \\
(\mathrm{~g} / \mathrm{cm})\end{array}$} \\
\hline & & Duodenum & Jejunum & Ileum & & \\
\hline NC & $188.10^{\mathrm{ab}}$ & 16.21 & 42.30 & 41.46 & 90.42 & $0.48^{\mathrm{bc}}$ \\
\hline PC & $185.48^{\mathrm{abc}}$ & 15.93 & 42.52 & 41.53 & 89.05 & $0.47^{\mathrm{bc}}$ \\
\hline $\mathrm{T} 1$ & $186.03^{\mathrm{ab}}$ & 14.02 & 42.40 & 43.55 & 87.97 & $0.46^{\mathrm{c}}$ \\
\hline $\mathrm{T} 2$ & $193.20^{\mathrm{a}}$ & 15.61 & 42.43 & 41.91 & 96.11 & $0.49^{\mathrm{abc}}$ \\
\hline T3 & $181.16^{\mathrm{abc}}$ & 14.71 & 42.33 & 42.93 & 101.76 & $0.56^{\mathrm{ab}}$ \\
\hline T4 & $181.15^{\mathrm{abc}}$ & 16.50 & 41.35 & 42.15 & 84.56 & $0.46^{c}$ \\
\hline T5 & $176.22^{\mathrm{bc}}$ & 14.95 & 42.58 & 42.47 & 100.67 & $0.57^{\mathrm{a}}$ \\
\hline T6 & $171.76^{\mathrm{c}}$ & 14.77 & 41.81 & 43.41 & 75.98 & $0.44^{\mathrm{c}}$ \\
\hline SEM & 4.380 & 1.093 & 1.004 & 1.047 & 6.096 & 0.028 \\
\hline$P$-value & 0.0311 & 0.7430 & 0.9889 & 0.7585 & 0.0739 & 0.0220 \\
\hline
\end{tabular}


At 35 days old, the length of the small intestine and the W/L were affected $(P=0.031$ and $P=0.022$, respectively) by treatments, while the weight of the intestine and the proportion of the length of small intestine parts did not show differences among treatments $(P>0.05)($ Table 3$)$. The authors noted that there was an improvement in intestinal morphology with age, in which a shorter small intestine was recorded from birds that received $60 \mathrm{~g}$ clove powder $/ \mathrm{kg}$ of diet (T6) than in all other treatments. On the other hand, T5 birds had a higher W/L compared with NC, PC, T1, T4 and T6, but not with treatments T2 and T3.

The interpretation of functional changes of the small intestine according to weight and length is often problematic. Thus, it is more interesting to assess changes in the intestinal function using histological approaches, which would indicate improved function (Awad et al., 2011) and intestinal health (Al-Baadani et al., 2016). Histomorphometric measurements of the intestinal ileum were affected $(P<0.001)$ by dietary treatments at 35 days old (Table 4). The tissues of the birds in the PC that were vaccinated were significantly higher in the height of the villus compared with NC, whereas villus width, surface area, crypt depth, and the ratio of villus height to villus-crypt depth did not show significant differences between PC and NC.

Table 4 Effect of clove powder levels on histomorphometric measurements of intestinal ileum section in broiler chickens at 35 days old

\begin{tabular}{|c|c|c|c|c|c|}
\hline \multirow[b]{2}{*}{ Treatment } & \multicolumn{5}{|c|}{ Parameters } \\
\hline & $\begin{array}{c}\text { Villus length } \\
(\mu \mathrm{m})\end{array}$ & $\begin{array}{l}\text { Villus width } \\
(\mu \mathrm{m})\end{array}$ & $\begin{array}{c}\text { Villus surface } \\
\text { area }\left(\mathrm{mm}^{2}\right)\end{array}$ & $\begin{array}{c}\text { Villus crypt-depth } \\
(\mu \mathrm{m})\end{array}$ & $\begin{array}{l}\text { Villus length/ crypt- } \\
\text { depth }(\mu \mathrm{m})\end{array}$ \\
\hline NC & $546.5^{\mathrm{b}}$ & $85.4^{\mathrm{a}}$ & $0.148^{\mathrm{a}}$ & $70.5^{a}$ & $7.82^{\mathrm{b}}$ \\
\hline PC & $621.1^{\mathrm{a}}$ & $83.1^{\mathrm{ab}}$ & $0.162^{\mathrm{a}}$ & $71.4^{\mathrm{a}}$ & $8.94^{\mathrm{ab}}$ \\
\hline $\mathrm{T} 1$ & $527.9^{b}$ & $77.9^{\mathrm{b}}$ & $0.127^{\mathrm{b}}$ & $62.2^{\mathrm{b}}$ & $10.05^{a}$ \\
\hline T2 & $439.5^{c}$ & $63.6^{c}$ & $0.085^{d}$ & $63.8^{a}$ & $7.09^{b}$ \\
\hline T3 & $427.4^{c}$ & $78.6^{\mathrm{ab}}$ & $0.108^{c}$ & $51.1^{\mathrm{c}}$ & $8.65^{\mathrm{ab}}$ \\
\hline T4 & $355.3^{d}$ & $62.1^{\mathrm{c}}$ & $0.069^{\mathrm{e}}$ & $51.4^{\mathrm{C}}$ & $7.01^{\mathrm{b}}$ \\
\hline T5 & $321.3^{\mathrm{de}}$ & $62.8^{\mathrm{c}}$ & $0.061^{\mathrm{e}}$ & $44.9^{d}$ & $7.17^{b}$ \\
\hline T6 & $295.2^{\mathrm{e}}$ & $62.0^{c}$ & $0.057^{\mathrm{e}}$ & $36.7^{\mathrm{e}}$ & $8.30^{\mathrm{ab}}$ \\
\hline SEM & 17.035 & 2.438 & 0.005 & 1.697 & 0.704 \\
\hline$P$-value & $<.0001$ & $<.0001$ & $<.0001$ & $<.0001$ & 0.0272 \\
\hline
\end{tabular}

\footnotetext{
${ }^{a-e}$ Mean value within a column with different superscripts is significantly different $P<0.001$. Data effect of treatment is a means of eight replicate birds $(n=8)$ of dietary treatment each.

NC: negative control, without addition of clove powder and not vaccination; PC: positive control without addition of clove powder and vaccination; T1, T2, T3, T4, T5, and T6: various levels of clove powder $(10,20,30,40,50$, and $60 \mathrm{~g} / \mathrm{kg}$ diet, respectively) and vaccination

SEM: standard error of the mean
}

The inclusion of various levels of clove powder (ascending levels from 10 to $60 \mathrm{~g} / \mathrm{kg}$ ) in dietary treatments resulted in a gradual decrease in villus height, villus surface area and villus crypt depth compared with the PC treatment. Mohamed et al. (2014) reported that a reduction of the surface of the villus indicates a lack of improvement in intestinal health and a lack of nutrient uptake capacity. On the other hand, villus width was significantly higher in the birds of T1 and T3 than those in T2, T4, T5, and T6, but there were not significantly different from the PC. In addition, the proportion of villus height to villus crypt depth was significantly higher in the birds of T1 compared with $\mathrm{T} 2, \mathrm{~T} 4$, and T5, but not significantly different from T3, T6 and PC.

Previous reports showed that as the villus height increases, both of the digestive and absorptive functions of the intestine increase, thus enhancing absorptive surface area, expression of brush border enzymes, nutrient transport systems and bodyweight (Awad et al., 2009; Mohamed et al., 2014). However, many substances can affect internal villi development, thus enterocyte enzymatic activity and structure are two essential features of the intestinal mucosal physiology (Awad et al., 2008). The inclusion of various levels of clove powder resulted in a gradual decrease in length, width and surface area of the villus, and may be due to suppressing of the beneficial bacteria in the gut. These findings are in line with the results of Cortés-Rojas et al. (2014), who reported that cloves extract have robust microbial activity in the small 
intestine. In addition, birds fed high levels of cloves may suffer from the adverse effect on the intestinal epithelium that leads to mucosal damage, so the most commonly used standards for evaluating abdominal mucosal injury and health in poultry are villus length, crypt depth and villus/crypt ratio (Budd et al., 2017; Ducatelle et al., 2018).

The villus crypt is regarded as the villus factory and deeper crypts indicate fast tissue turnover to permit renewal of the villus as needed in response to normal sloughing (Yason et al., 1987). A reduction of the villus height and deeper crypts may lead to poor nutrient absorption, increased secretion in the internal tract, and lower performance (Xu et al., 2003). In contrast, Awad et al. (2009) reported that increases in the villus length and villus/crypt ratio correlated with increased epithelial cell turnover and longer villi are associated with activated cell mitosis.

The results of the histopathological changes in the small intestine from the various treatments are presented in Figure 1. Birds that were fed on the unsupplemented diet and were not vaccinated (NC) showed regular intestinal villus and muscular layers with thickening of some villi. The PC showed regular intestinal villi with desquamated epithelial cells in the lumen, and regenerative attempts from the lower villus epithelium and intestinal crypts.

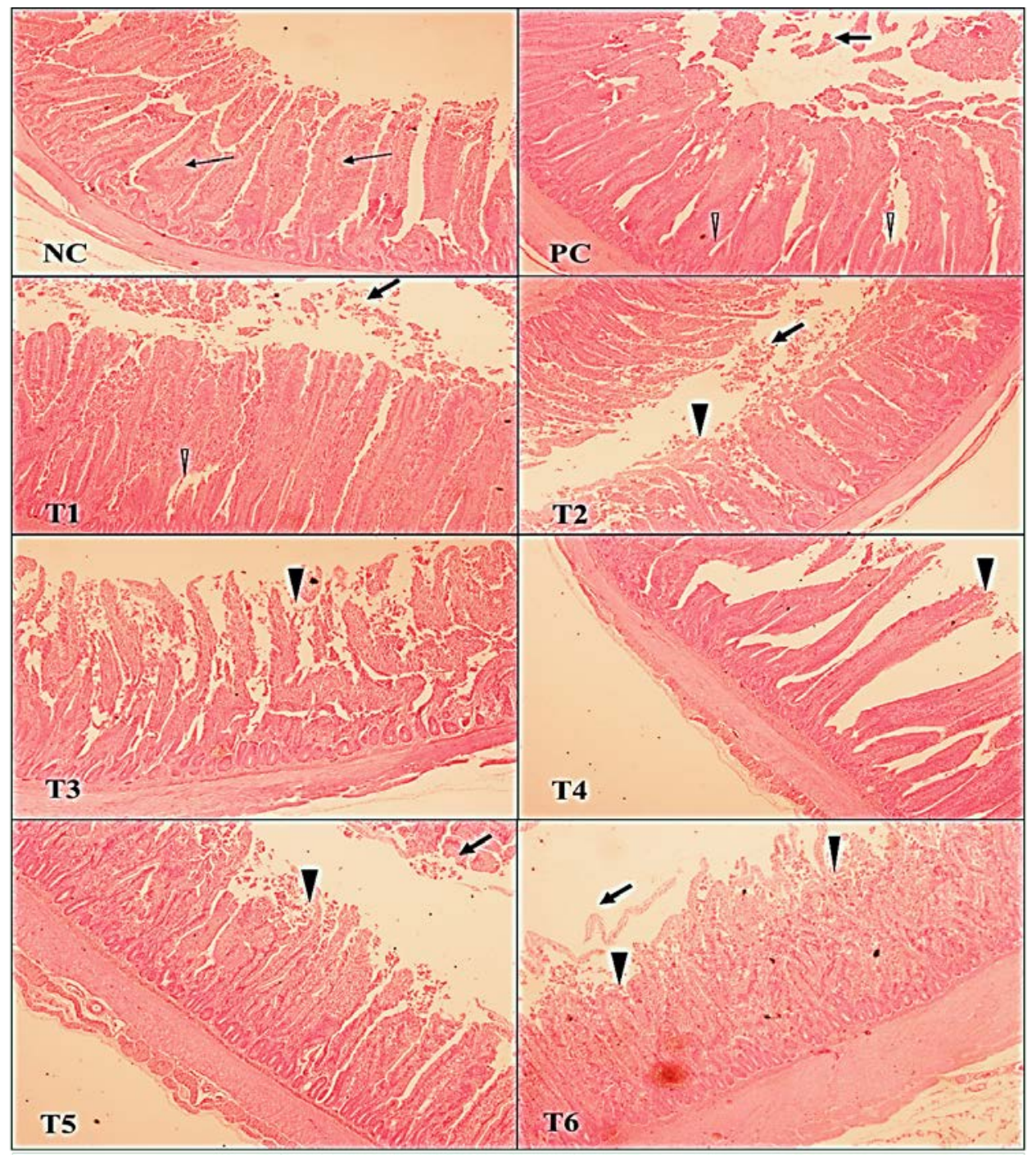

Figure 1 Histological changes in the ileum of broilers

NC: negative control without vaccination, PC: positive control with vaccination, regular intestinal mucosal except thickening of some villi $(\uparrow)$ in NC \& desquamated epithelial cells in the lumen $(\uparrow)$ with regenerative attempts from the lower villus epithelium and intestinal crypts $(\Delta)$ in PC. In T1 (10 g of cloves/ $\mathrm{kg}$ of diet with vaccination), the villus is more regular compared with the control with desquamated epithelial cells in the lumen $(\uparrow)$ and regenerative attempts from the lower villus epithelium and intestinal crypts $(\Delta)$. Birds that fed on T2 to T6 $(20,30,40,50$ and $60 \mathrm{~g}$ clove powder per kg of diet with vaccination, respectively) show disorganized villi with fusion in villus tips and necrotic enteritis on the wall of villi $(\Delta)$, accumulation of mucus and desquamated intestinal sheets in the lumens $(\uparrow)$. Haematoxylin and eosin (x 100). 
The addition of clove powder in T1 (1\%) showed villi height and width within the normal range. In addition, intestinal villi have proliferative enterocytes, so some villi appeared to fuse with others and the lumen contained sheets of epithelium cells. Other treatments with clove powder (T2 to T6) showed necrotic enteritis on the wall of villi, which is characterized by gradual loss of tissue structure with an increased level of cloves and accumulation of mucus and desquamated intestinal sheets in the lumens.

The results of histopathological changes in the liver from the various treatments are presented in Figure 2. Birds in the control treatments (NC and PC) showed no histopathological changes through the normal distribution of hepatocytes, clear visible nuclei and central vein. The livers of birds that received $10 \mathrm{~g}$ clove powder/kg diet (T1) showed normal hepatocytes and leukocyte infiltration around the central vein, with dilation of the central vein. Dietary supplementation with clove powder (T2 to T6) showed swollen hepatocytes and dilates of the hepatic sinusoids which separate between hepatic cords. On the other hand, the liver of T2 birds showed periductal leukocyte infiltration by these inflammations. There was also a loss of lining endothelial cells in T3 and central vein stenosis in T6, whereas there was a dilation of the central vein in other treatments.

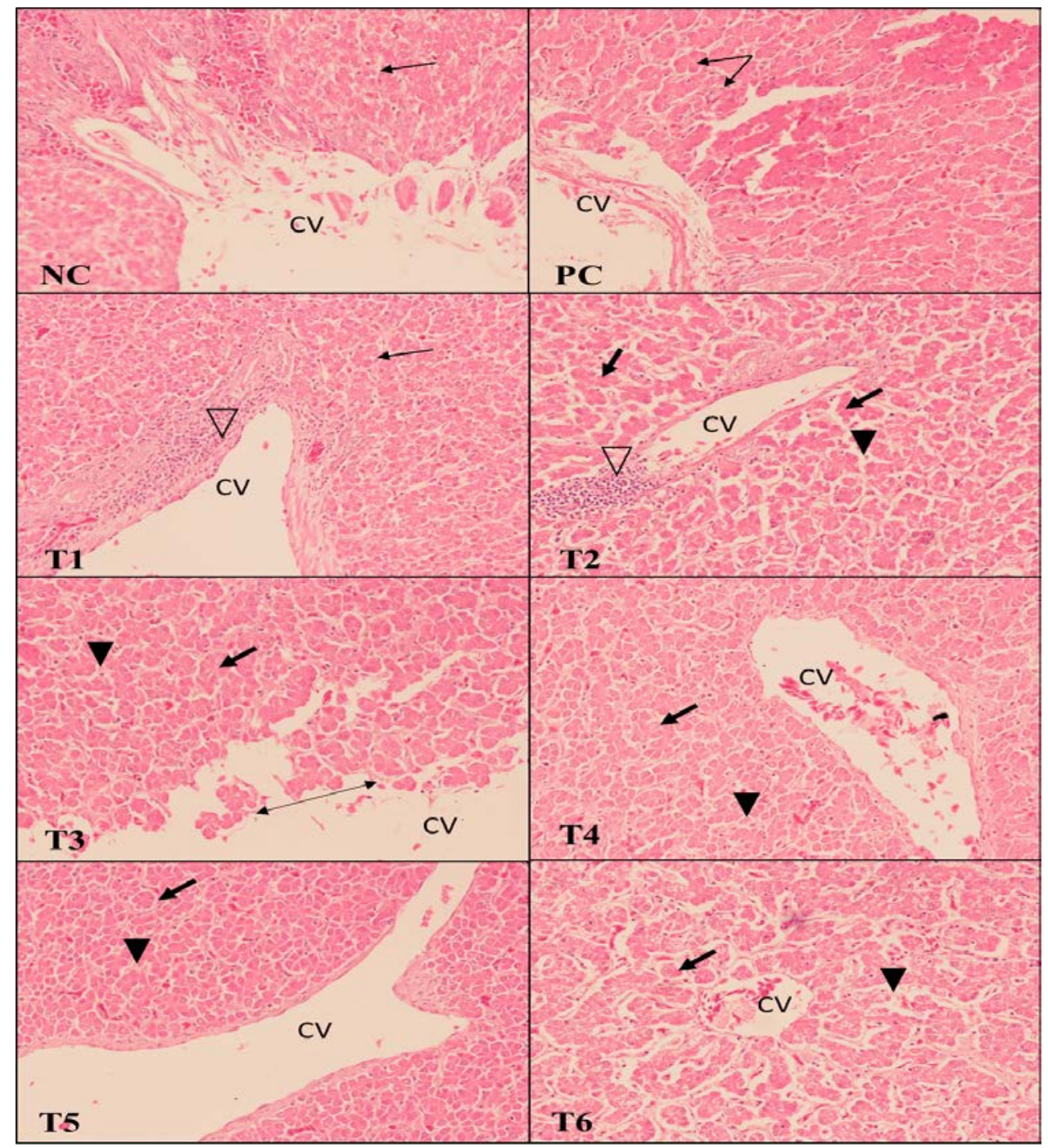

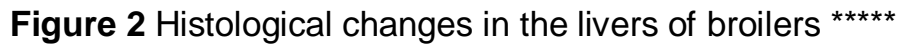

NC: negative control without vaccination \& PC: positive control with vaccination, normal distribution of hepatocytes ( $\uparrow)$ with dilation of central vein (CV). T1: $10 \mathrm{~g}$ clove powder/kg diet with vaccination, hepatocytes normal $(\uparrow)$, leukocytes infiltration around the central vein $(\Delta)$ and dilation of central vein (CV). Whereas, birds that fed on diet T2 to T6 (20, 30 , 40, 50 and $60 \mathrm{~g}$ clove powder per $\mathrm{kg}$ of diet with vaccination, respectively) showed swollen hepatocytes ( $\uparrow)$ and dilation of sinusoid spaces $(\boldsymbol{\Delta})$. In addition, leukocytes infiltration around the central vein in T2 $(\Delta)$, loss of lining endothelial cells in T3 $(\mathfrak{\imath})$ and central vein stenosis in T6 (CV). Haematoxylin and eosin (x 400). 
The liver is the primary site of nutrient metabolism in the body (Rahman et al., 2017). Cloves are one of the most abundant sources of dietary polyphenols with many traditional medicinal uses (Jose et al., 2017). Cloves contain a eugenol compound, which mitigates thioacetamide-induced liver damage (Ali et al., 2014). However, it has been found that clove essential oil and clove extracts have hepatoprotective effects through reducing liver toxicity (Al-Okbi et al., 2014; El-Hadary \& Ramadan, 2016). No reports on the histological changes of the liver through the use of cloves in broilers have been reported before. The results obtained in this study indicated that the use of more than $1 \%$ cloves has a gradual adverse effect on the liver. These results agree with those of Nwaopara et al. (2007) who found that excessive consumption of cloves could affect the liver hepatocytes in rabbits. Abdel-Rahman et al. (2006) found that the addition of $500 \mathrm{mg} / \mathrm{kg}$ of clove powder in the diet of mice improved the histology of hepatic cells. Yet another study reported that cloves did not show any effect on the enzyme activity in the liver of rabbits (Kazi et al., 2017) or bring about histological changes in liver tissues (Velisek et al., 2005).

\section{Conclusions}

The authors concluded from this study that the highest appropriate level for the inclusion of clove powder is $1 \%$ (10 g/kg of diet) when added to poultry diets, which is not different from the growth rate and histological changes of the intestines and liver (normal liver and intestine tissues) in broiler chickens. Additionally, being vaccinated against diseases in this study did not affect the bodyweight and relative weights of the liver and intestines or bring about histological changes.

\section{Acknowledgments}

The authors would like to extend their sincere appreciation to the Deanship of Scientific Research, Research Centre, at King Saud University, for funding this research.

\section{Authors' Contributions}

$\mathrm{SI}, \mathrm{HH}$ and $\mathrm{EH}$ designed, conducted the growth trial, collected the samples from the birds and statistical analyses. $\mathrm{HH}$ did the histological slides. SI interpreted the slides and prepared the figures. $\mathrm{HH}$ wrote the manuscript and submitted the manuscript.

\section{Conflict of Interest Declaration}

There is no conflict of interest.

\section{References}

Abdel-Rahman, M.K. \& El-Megeid, A.A.A., 2006. Hepatoprotective effect of soapworts (Saponaria officinalis), pomegranate peel (Punica granatum L) and cloves (Syzygium aromaticum linn) on mice with $\mathrm{CCl}$ hepatic intoxication. World J. Chemist. 1, 41-46.

Abudabos, A.M., Al-Batshan, H.A. \& Murshed, M.A., 2015. Effects of prebiotics and probiotics on the performance and bacterial colonization of broiler chickens. S. Afr. J. Anim. Sci. 45, 419-428.

Adam, S.I., Mohamed, S.B. \& Abdelgadir, W.S., 2013. Effects of the aqueous extract of clove (Syzygium aromaticum) on Wistar Rats. Br. J. Pharmacol. Toxicol. 4, 262-266.

Agostini, P.S., Sola-Oriol, D., Nofrarias, M., Barroeta, A.C., Gasa, J. \& Manzanilla, E.G., 2012. Role of in-feed clove supplementation on growth performance, intestinal microbiology, and morphology in broiler chicken. Livest. Sci. $147,113-118$

Al-Baadani, H.H., Abudabos, A.M., Al-Mufarrej, S.I. \& Alzawqari, M., 2016. Effects of dietary inclusion of probiotics, prebiotics, and symbiotics on intestinal histological changes in challenged broiler chickens. S. Afr. J. Anim. Sci. 46, 157-165.

Ali, S., Prasad, R., Mahmood, A., Routray, I., Shinkafi, T.S., Sahin, K. \& Kucuk, O., 2014. Eugenol-rich fraction of Syzygium aromaticum (clove) reverses biochemical and histopathological changes in liver cirrhosis and inhibits hepatic cell proliferation. Eur. J. Cancer Prev. 19, 288-300 .

Al-Okbi, S.Y., Mohamed, D.A., Hamed, T.E. \& Edris, A.E., 2014. Protective effect of clove oil and eugenol microemulsions on fatty liver and dyslipidemia as components of metabolic syndrome. J. Med. Food. 17, 764-771.

Amaechi, N. \& Anueyiagu, C.F., 2012. The effect of dietary benzoic acid supplementation on growth performance and intestinal wall morphology of broilers. Online J. Anim. Feed Res. 1, 401-404.

Awad, W., Ghareeb, K. \& Böhm, J., 2008. Intestinal structure and function of broiler chickens on diets supplemented with a synbiotic containing Enterococcus faecium and oligosaccharides. Int. J. Mol. Sci. 9, 2205-2216.

Awad, W.A., Ghareeb, K. \& Abdel-Raheem, S., 2009. Effects of dietary inclusion of probiotic and symbiotic on growth performance, organ weights and intestinal histomorphology of broiler chickens. Poult. Sci. 88, 49-56.

Awad, W.A., Ghareeb, K. \& Böhm, J., 2011. Evaluation of the chicory inulin efficacy on ameliorating the intestinal morphology and modulating the intestinal electrophysiological properties in broiler chickens. J. Anim. Physiol. Anim. Nutr. 95, 65-72.

Belih, S.S., Labib, Z.M. \& Ragab, A.M., 2015. Role of Saltose probiotic for the control of the experimental infection of the clostridium perfringens and the coccidia in chickens. Asian J. Vet. Sci. 46, 20-41. 
Budd, G.R., Aitchison, A., Day, A.S. \& Keenan, J.I., 2017. The effect of polymeric formula on enterocyte differentiation. Innate Immun. 23, 240-248.

Bryden, W.L., Li, X., Ravindran, G., Hew, L.I. \& Ravindran, V., 2009. Ileal digestible amino acid values in feedstuffs for poultry. Rural Industries Research and Development Corporation, Canberra, Australia 76, 9-71.

Castanon, J.I.R., 2007. History of the use of antibiotic as growth promoters in European poultry feed. Poult. Sci. 86, 2466-2471.

Cortés-Rojas, D.F., de Souza, C.R. \& Oliveira, W.P., 2014. Clove (Syzygium aromaticum): A precious spice. Asian. Pac. J. Trop. Biomed. 4, 90-96.

Chowdhury, S., Mandal, G.P., Patra, A.K., Kumar, P., Samanta, I., Pradhan, S. \& Samanta, A.K., 2018. Different essential oils in diets of broiler chickens: 2. Gut microbes and morphology, immune response, and some blood profile and antioxidant enzymes. Anim. Feed Sci. Technol. 236, 39-47.

Daniel, A.N., Sartoretto, S. M., Schmidt, G., Caparroz-Assef, S.M., Bersani-Amado, C.A. \& Cuman, R.K., 2009. Antiinflammatory and antinociceptive activities $A$ of eugenol essential oil in experimental animal models. Rev. Bras. Farmacogn.-Braz. J. Pharmacogn. 19, 212-217.

Dorman, H.J. \& Deans, S.G., 2000. Antimicrobial agents from plants: Antibacterial activity of plant volatile oils. J. Appl. Microbiol. 88, 308-316.

Ducatelle, R., Goossens, E., Meyer, F., Eeckhaut, V., Antonissen, G., Haesebrouck, F. \& Immerseel, F., 2018. Biomarkers for monitoring intestinal health in poultry: Present status and future perspectives. Vet. Res. 49, 43.

El-Hadary, A.E. \& Ramadan, M.F., 2016. Hepatoprotective effect of cold-pressed Syzygium aromaticum oil against carbon tetrachloride (CCl4)-induced hepatotoxicity in rats. Pharm. Biol. 54, 1364-1372.

Ertas, O.N., Guler, T., Ciftci, M., Dalkilic, B. \& Simsek, G., 2005. The effect of an essential oil mix derived from oregano, clove and anise on broiler performance. Int. J. Poult. Sci. 4, 879-884.

Ghazanfari, S., Mohammadi, Z. \& Adibmoradi, M., 2014. Effects of clove essential oil on growth performance, carcass characteristics and immune system in broiler chicken. Vet. J. 19, 212-217.

Jose, S.P., Ratheesh, M., Asha, S., Krishnakumar, I.M., Sandya, S. \& Girish, K.B., 2017. Hepato-protective effect of clove bud polyphenols (Syzygium aromaticum L.) (Clovinol $\left.{ }^{\circledR}\right)$ by modulating alcohol induced oxidative stress and inflammation. J. Food Res. 7, 10-20.

Kazi, S., Ansari, M.A., Memon, A.R., Memon, A.R. \& Phull, Q.Z., 2017. Reversal of paracetamol induced hepatotoxicity in animals model: Clove, an alternative medicine beyond the spices. J. Liaquat. Uni. Med. Health Sci. 16, 154-157.

Kreydiyyeh, S.I., Usta, J. \& Copti, R., 2000. Effect of cinnamon, clove and some of their constituents on the Na+-K+ATPase activity and alanine absorption in the rat jejunum. Food Chem. Toxicol. 38, 755-762.

Li-Ming, B., Eerdunbayaer, A.N., Eizo, T., Keinosuke, O., Hideyuki, I. \& Tsutomu, H., 2012. Hydrolysable tannins Isolated from Syzygium aromaticum: Structure of a new C-Glucosidic ellagitannin and spectral features of tannins with a tergalloyl group. Heterocycles 85, 365-381.

Mahrous, H.S., El-Far, A.H., Sadek, K.M. \& Abdel-Latif, M.A., 2017. Effects of different levels of clove bud (Syzygium aromaticum) dietary supplementation on immunity, antioxidant status, and performance in broiler chickens. A. J. V. S. 54, 29-39.

Mohamed, M.A., El-Daly, E.F., El-Azeem, N.A., Youssef, A.W. \& Hassan, H.M.A., 2014. Growth performance and histological changes in ileum and immune related organs of broilers fed organic acids or antibiotic growth promoter. Int. J. Poult. Sci. 13, 602-610.

Nadkarni, K.M., 2000. Myrtus caryophyllus. In: K.M. Nadkarni (ed). Materia medica. Popular Prakashan Pvt. Ltd., Mumbai, India 2, 835-836.

Najafi, P. \& Torki, M., 2010. Performance, blood metabolites and immune competence of broiler chicks fed diets induced essential oils of medicinal herbs. J. Anim. Vet. Adv. 9, 1164-1168.

Nicholson, J.K., Holmes, E., Kinross, J., Burcelin, R., Gibson, G., Jia, W. \& Pettersson, S., 2012. Host-gut microbiota metabolic interactions. Science 1262-1267.

Nwaopara, A.O., Odike, M.A.C., Inegbenebor, U. \& Adoye, M.I., 2007. The combined effects of excessive consumption of ginger, clove, red pepper and black pepper on the histology of the liver. Pak. J. Nutr. 6, 524-527.

Rahman, A.M., Mahdavi, A.H., Rahmani, H.R. \& Jahanian, E., 2017. Clove bud (syzygium aromaticum) improved blood and hepatic antioxidant indices in laying hens receiving low n-6 to n-3 ratios. J. Anim. Physiol. Anim. Nutr. 101, 881-892.

Rosin, E.A., Blank, G., Slominski, B.A. \& Holley, R.A., 2007. Enzyme supplements in broiler chicken diets: In vitro and in vivo effects on bacterial growth. J. Sci. Food Agric. 87, 1009-1020.

SAS, 2008. Statistical analysis systems users guide: Statistics. SAS Institute Inc., Cary, NC., USA.

Smith, D.L., Johnson, J.A., Harris, A.D., Furuno, J.P., Perencevich, E.N. \& Morris, J.G., 2003. Assessing risks for a preemergent pathogen: Virginiamycin use and the emergence of streptogramin resistance in Enterococcus faecium. Lancet Infec. Dis. 3, 241-249.

Svihus, B., 2014. Function of the digestive system. J. Appl. Poult. Res. 23, 306-314.

Tariq, H., Rao, P.R., Raghuvanshi, R.S., Mondal, B.C. \& Singh, S.K., 2015. Effect of aloe vera and clove powder supplementation on carcass characteristics, composition and serum enzymes of Japanese quails. Vet. World 8 , 664-668.

Tripathi, D., Kumar, A., Mondal, B.C., Rahal, A. \& Palod, J., 2013. Effect of ajwain, hot pepper and black pepper on performance of Japanese quails. Indian J. Anim. Nutr. 30, 431-433.

Velisek, J., Svobodova, Z., Piackova, V., Groch, L. \& Nepejchalova, L., 2005. Effects of clove oil anaesthesia on common carp (Cyprinus carpio L.). Vet. Med. 50, 269-275. 
Walum, E., 1998. Acute oral toxicity. Environ. Health Persp. 106, 497-503.

Xu, Z.R., Hu, C.H., Xia, M.S., Zhan, X.A. \& Wang, M.Q., 2003. Effects of dietary fructooligosaccharide on digestive enzyme activities, intestinal microflora and morphology of male broilers. Poult. Sci. 82, 1030-1036.

Yason, C.V., Summers, B.A. \& Schat, K.A., 1987. Pathogenesis of rotavirus infection in various age groups of chickens and turkeys: Pathology. Am. J. Vet. Res. 6, 927-938. 